\title{
Investigating the impact of physical-mental exercises on depression after preterm delivery: A clinical trial
}

\author{
$\underline{\text { Samane Haji Mohammad Khani }}{ }^{(\mathbb{D})}$, Zahra Abedian ${ }^{2}$ (D), Amin Azhari $^{3}(\mathbb{D}$, \\ Mohammad Taghi Shakeri ${ }^{4}$, Mahdi Talebi ${ }^{5}$ \\ ${ }^{1}$ Corresponding author; MSc Student of Midwifery Education, School of Nursing and Midwifery, Mashhad University of Medical Sciences, \\ ${ }^{3}$ Physical \& Rehabilitation Medicine clinic, Imam Reza (AS) Educational, Research and Medical Center, Mashhad University of Medical Sciences, \\ ${ }^{5}$ psychiatric clinic, Imam Reza (AS) Educational, Research and Medical Center, Mashhad University of Medical Sciences, Mashhad, Iran
} Mashhad, Iran

Tel: +989358900549Ｆax: +985138597313ＥＥmail: hajims961@mums.ac.ir

2 Department of Midwifery, School of Nursing and Midwifery, Mashhad University of Medical Sciences, Mashhad, Iran Mashhad, Iran

${ }^{4}$ Department of Biostatistics, school of health, Mashhad University of Medical Sciences, Mashhad, Iran

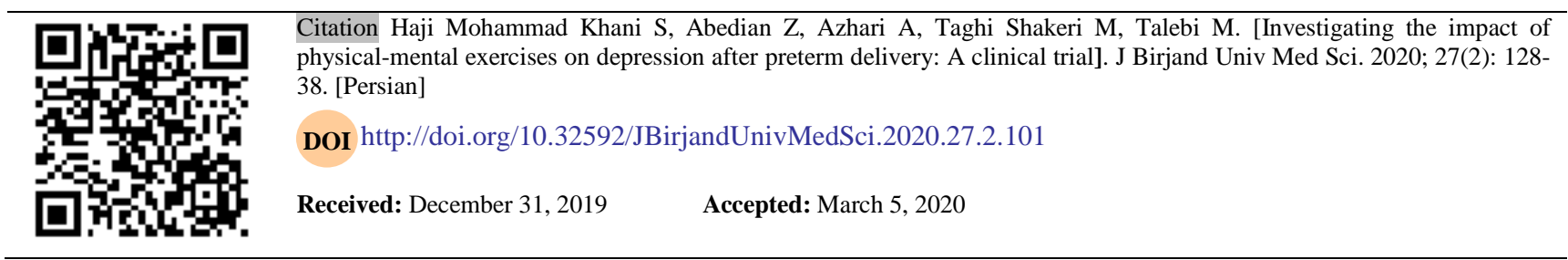

\begin{abstract}
Background and Aim: Preterm delivery, and the consequences are include premature newborn, hospitalization in the NICU ward, psychological damage to mother and heart family performing low-cost, practical interventions can play an important role in promoting maternal health by to reduce psychological trauma. Therefore, the present study was performed to determine the impact of physical-mental exercises on depression after preterm delivery.

Materials and Methods: In this clinical trial, 100 women with preterm delivery 28-36 weeks, it was performed in public hospitals in Mashhad in 2019. Sampling was performed by random blocking method and the subjects were selected by available method and were divided into two control groups $(n=50)$ and intervention $(n=50)$. The intervention group performed stretching exercises as well as meditation by the researcher on the third day after delivery with a frequency of two sessions per week for up to 8 sessions, and the control group received the usual care. Beck's depression questionnaire was completed for both groups in the first 24 hours after delivery and at the end of the study. Statistical analysis of the data was performed by independent t-test, Mann-Whitney and Wilkaxon.
\end{abstract}

Results: The mean score of depression in the intervention and control groups at the end of the study was statistically significant $(\mathrm{p} \leq 0.001)$. The mean score of depression in the intervention group was significant at the beginning and the end of the study $(\mathrm{P}<0.001)$.

Conclusion: Stretching exercises with a focus on the body after delivery can reduce the rate of depression in mothers with preterm delivery.

Key Words: Meditation; Postpartum Depression; Preterm Delivery; Stretching Exercise 


\title{
بروسى تأثير تمرينهاى جسمى - ذهنى بر افسردىى بعد از زايمان زودرس: يك كار آزمايى بالينى
}

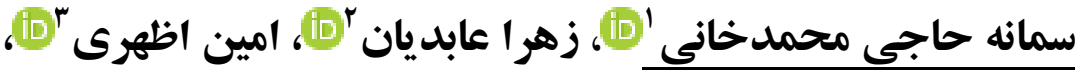

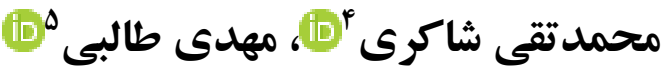

\begin{abstract}
جكيده

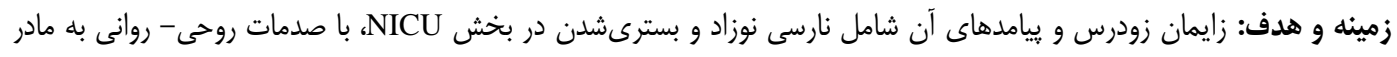

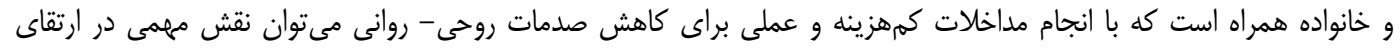

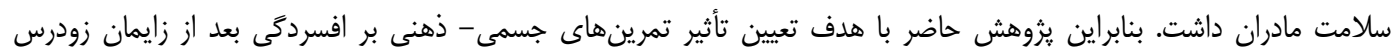

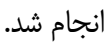

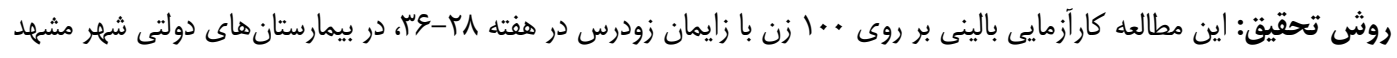

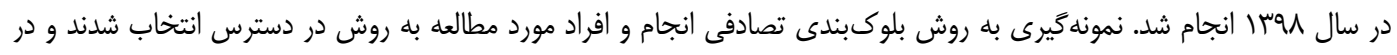

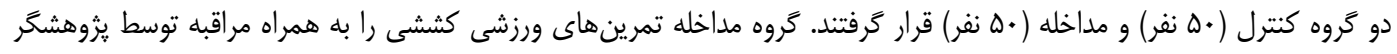

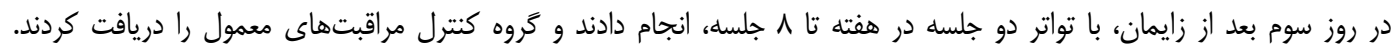

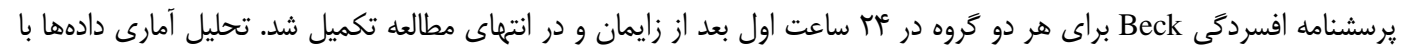

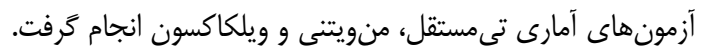

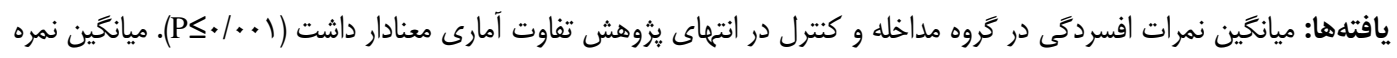

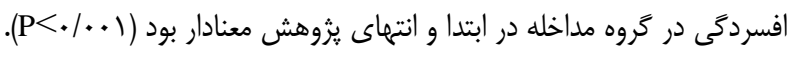

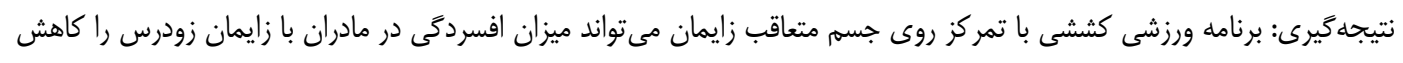

وازههاى كليدى: مراقبه؛ افسردحى بعد از زايمان؛ زايمان زودرس؛ ورزش كششى

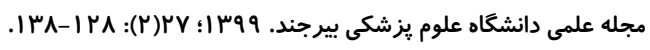
دريافت: • 
شده است. مادران با نوزادان نارس، در برقرارى ارتباط با نوزاد مقل مله

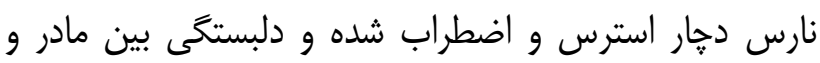

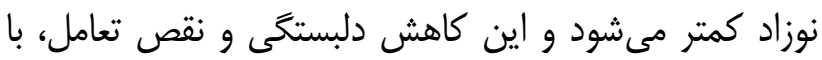

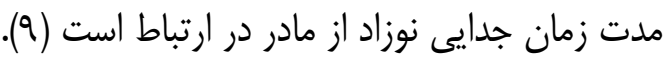

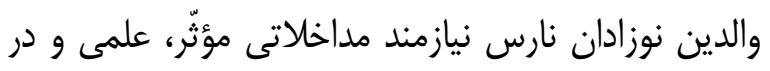

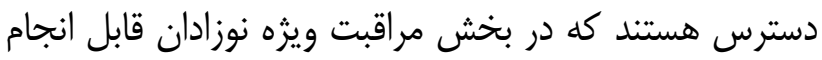
بوده و بتواند مادران را در امر مراقبت فعال از نوزاد دراد دخيل

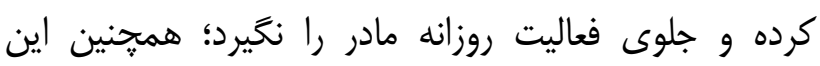
مداخلات بايد قابل انجام براى همه مادران در شرايط مشابه

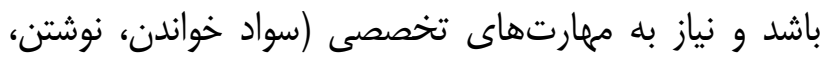

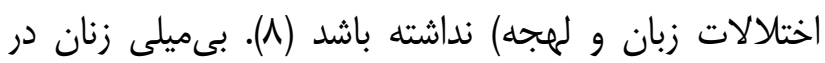

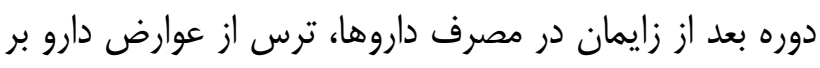

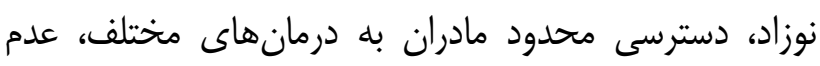

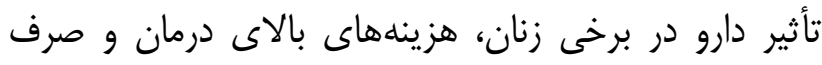

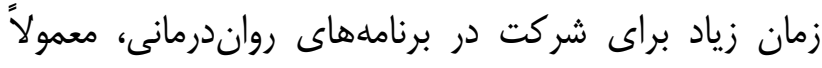

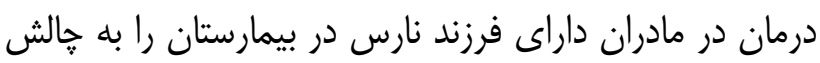

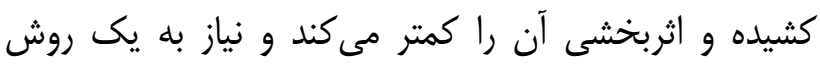

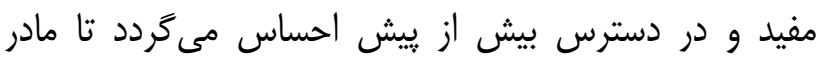

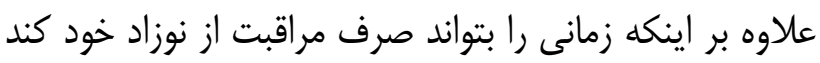

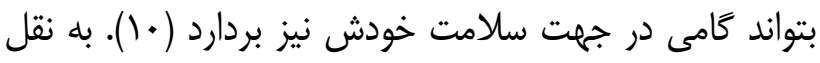

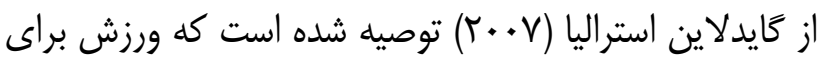

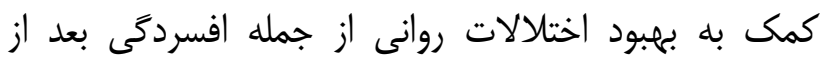

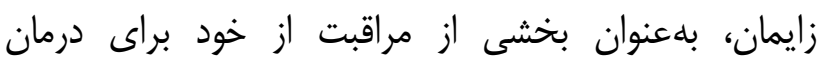

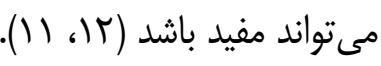

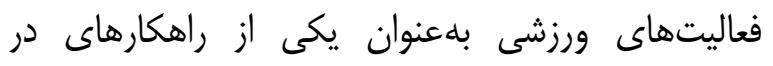
دسترس براى كاهش تنش عاطفى و جسمى مطرح است كه به الز

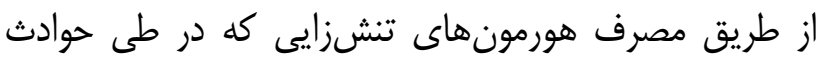

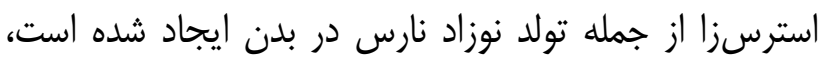

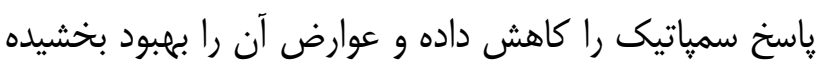

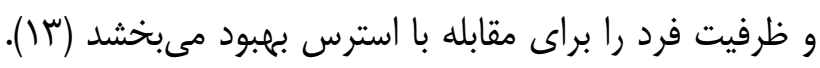

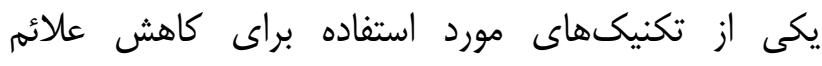

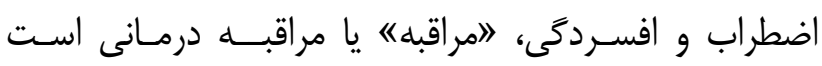

دوره بعد از زايمان، بهدليل اينكه اغلب تتييرات ناشى از

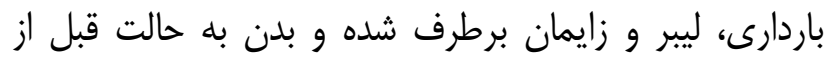

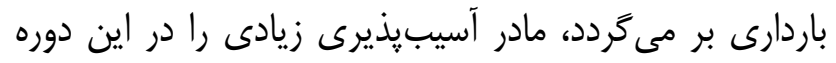

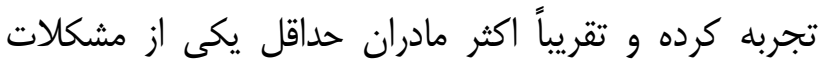

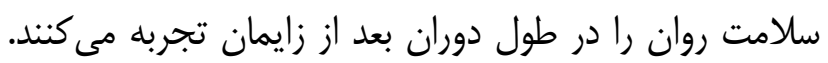

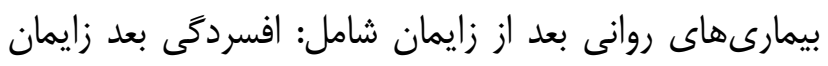

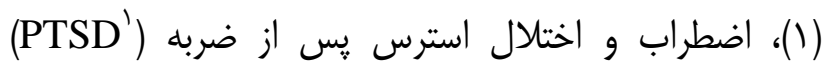

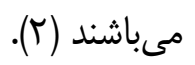

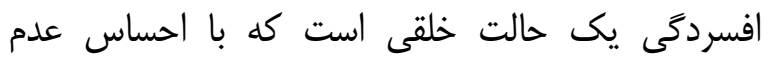

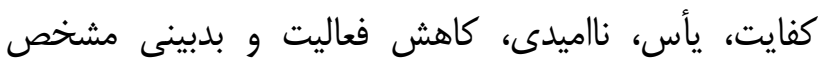

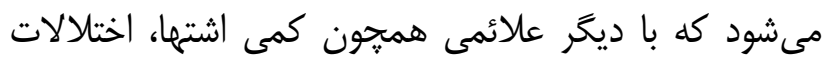

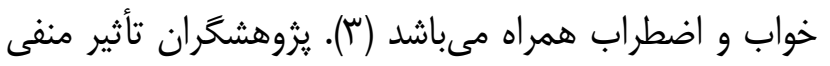

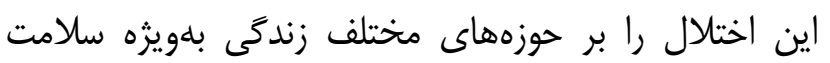
جسمى و روانى، عملكرد و رفتار با دوستان، خانواده، نحوه إنائ ارتباط با همسر و آرامش روانى كودكان، عملكرد اجتماعى و و ونان روابط بينفردى نشان دادهاند (أ).

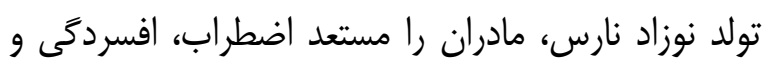

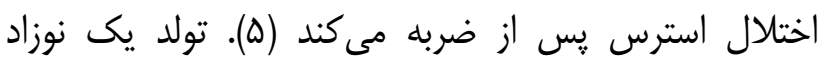

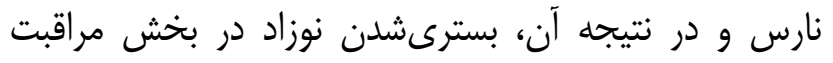

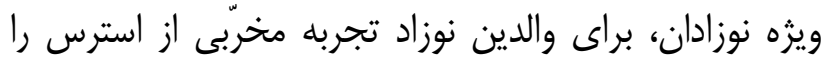

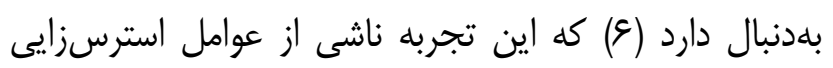

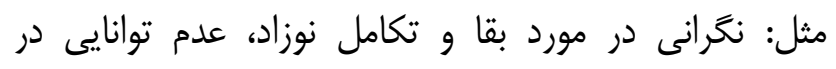

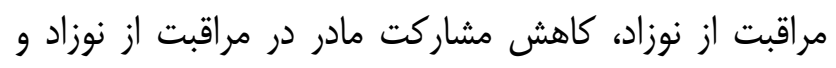

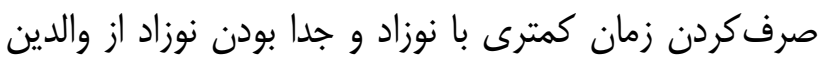

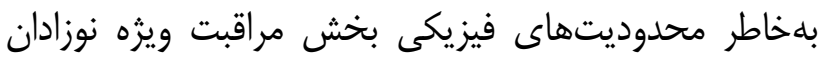

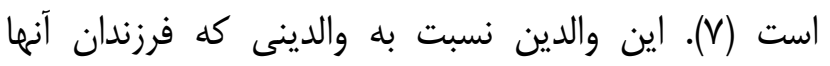

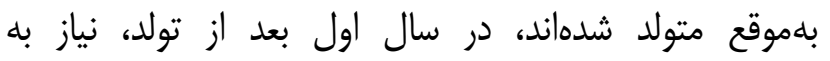
حمايتهاى روانى زيادى دارند (ه، \& \& ه). شيوع زايمان

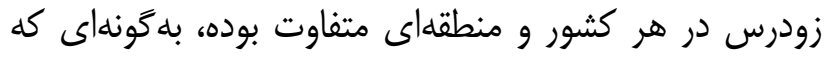

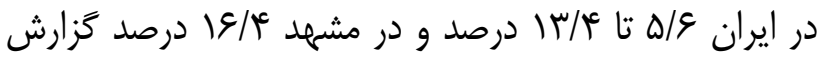


روش تحقيق

اين مطالعه كارآزمايى بالينى شاهددار تصادفىشده كه

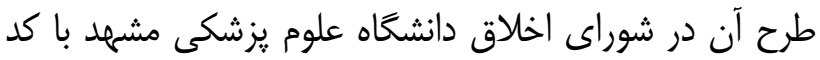

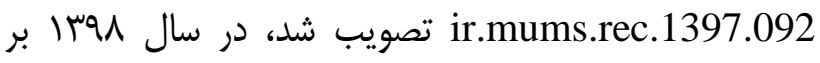
روى ..1 مادر با زايمان زودرس و نوزاد بسترى در بخش

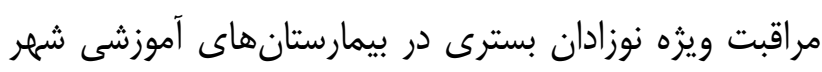

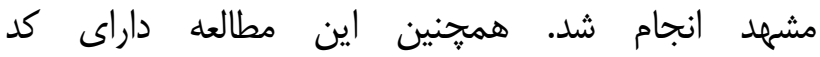

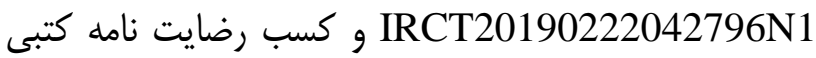
و آكاهانه از شركت كنندهها بود.

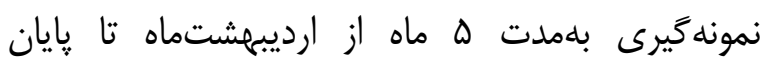

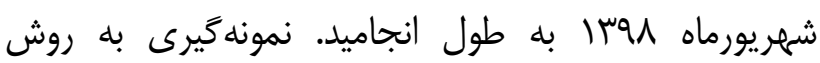

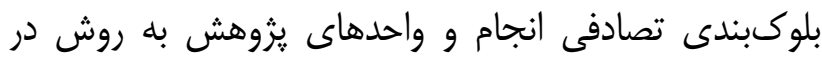

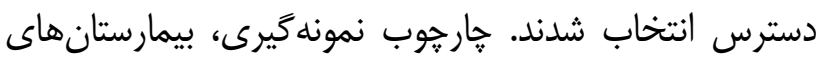

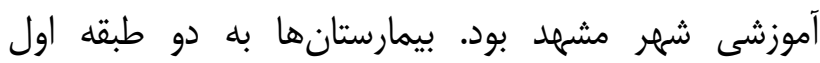

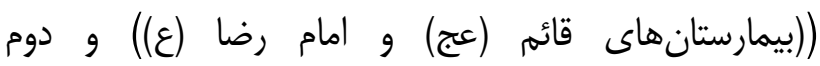

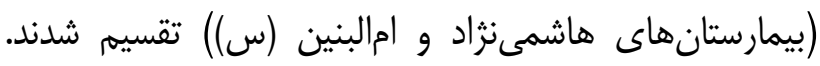

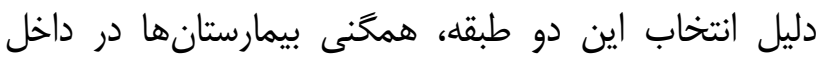

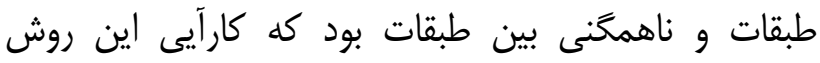
نمونه كَيرى را بهبود بخشيد. براى انتخاب يك بين بيمارستان در

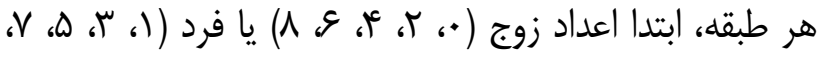

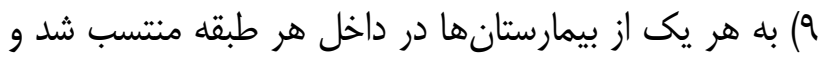

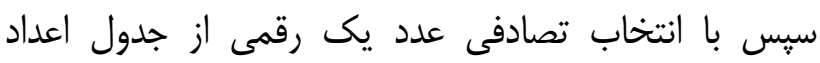

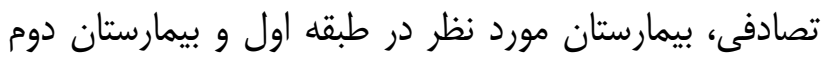
در طبقه دوم قرار كرفت و بدرين ترانيان

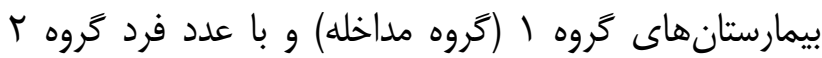

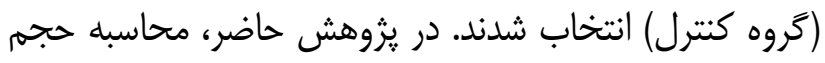
نمونه با فرمول مقايسه ميانخين دو جمعيت، با استفاده از نتايج

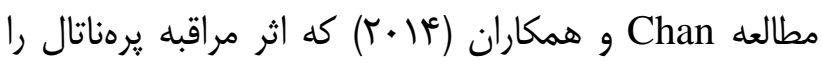

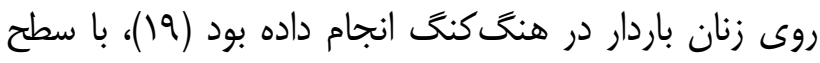

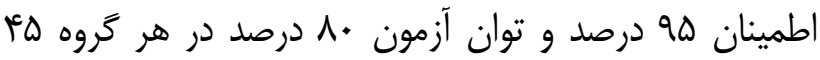

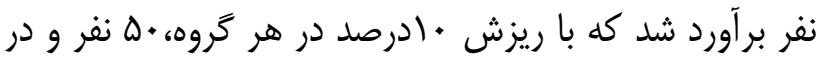
مجموع در هر دو گروه ... نفر محاسبه كَرديد.

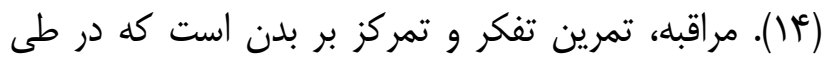

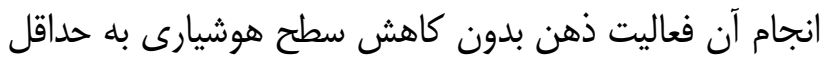

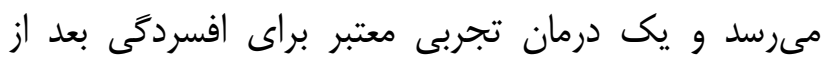

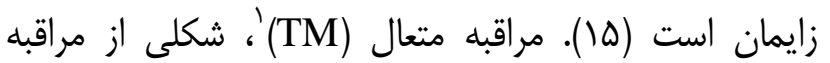
مانترا مىباشد كه در آن از يك روش آنه خاص استال استفاده مىشود. در اين روش، انجام مرتب تمرينات، سبب ايجاد انداد تغييرات درازمدت در سيستم سمياتيك شده كه با علائم كاهش فشتار خون، متابوليسم و واكنشيذيرى به استرس همر اه است (1) (1).

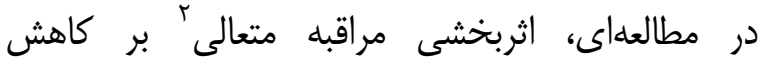

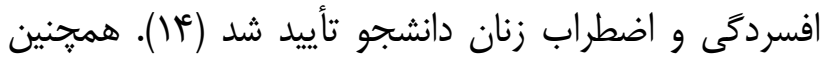
مشاهده كرديد كه ورزش بِ

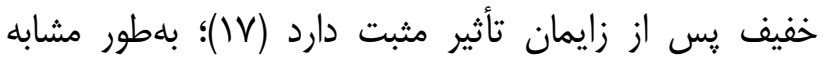

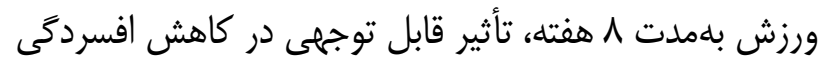

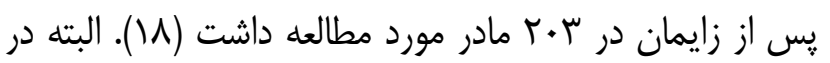

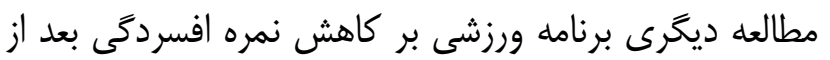

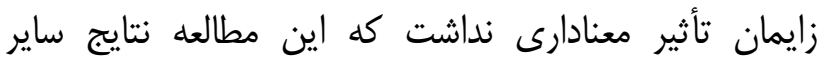
مطالعات را نقض كرد. بنابراين خلأ انجام يك مطالعه با بات توجه

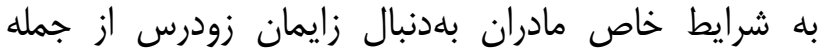

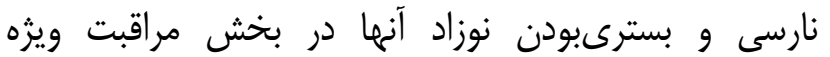
احساس شد. - است استرس مضاعف بر عوارض بعد از زايمان، مادران داراى نوزاد نارس را در معرض مشكلات روانشناختى ازجمانه افسردگى بعد از زايمان قرار مىدهد؛؛ بنابراين آنها نيازمند

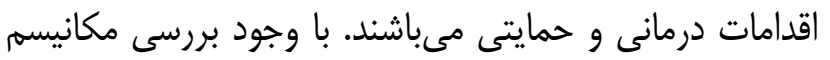

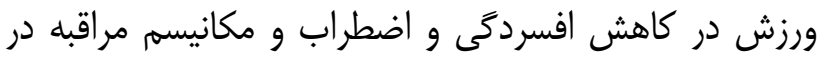

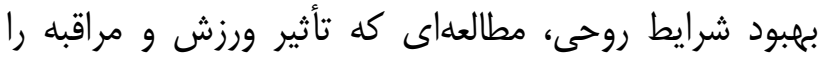

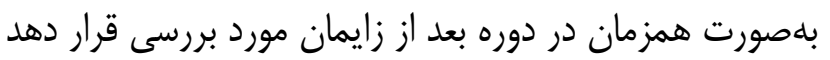

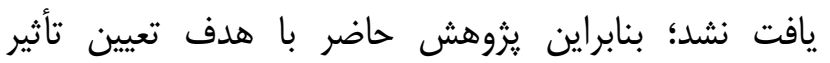
تمرينات جسمى - ذهنى بر افسردىى بعد از زايمان زودرس

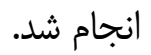

\footnotetext{
${ }^{1}$ Transcendental Meditation

${ }^{2}$ Meditation
} 
شده بود، براى اندازهگيرى افسردگى استفاده شد(·r). اين

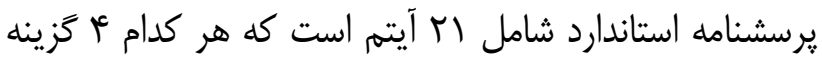
براى ياسخ داشته و از صفر تا ب نمرهدهى مى شود و نمره كل

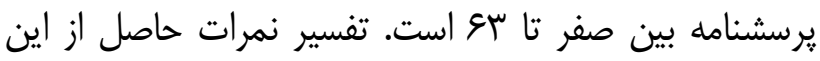

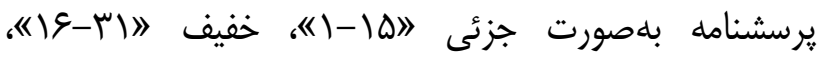

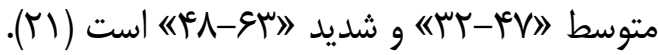
PAR-' يرسشنامه ارزيابى آمادگى براى فعاليت جسمانى

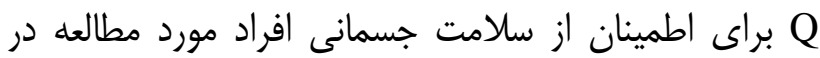

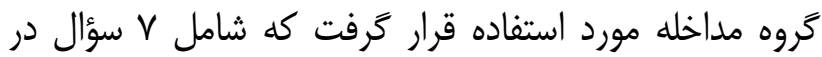

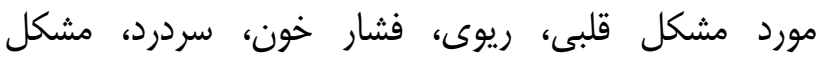

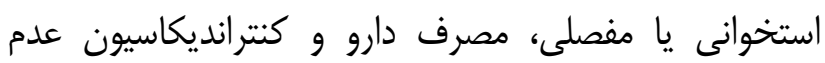
فعاليت جسمى بود. افراد مورد مطالعه در صورت دادئ دادن جواب

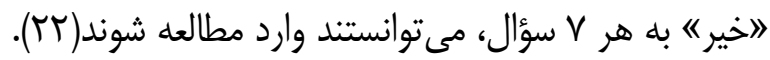

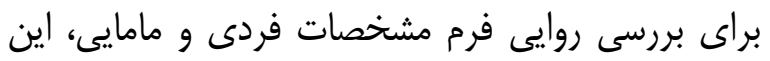

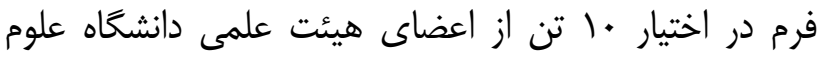
يزشكى مشهر قرار گرفت و يس از انجام اصلاحات و اعمال

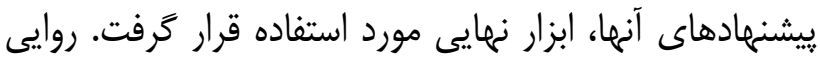

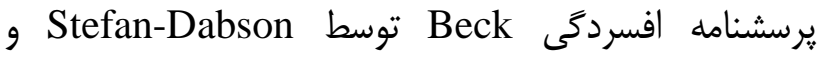
محمدخانى (عیىا) در تهران روى داوطلبين با افسردگى

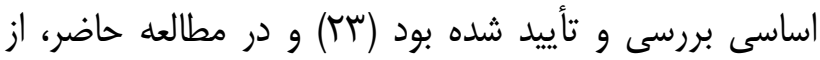
طريق روايى محتوى تعيين شد. پايايى اين ابزار در مطالعه Dobson

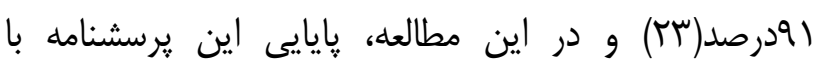

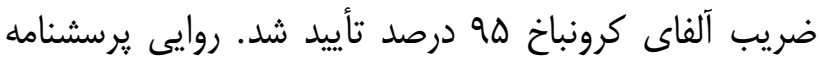

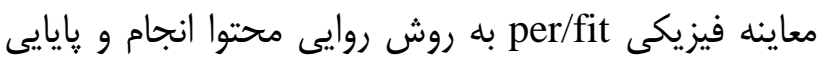

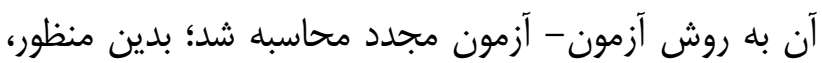

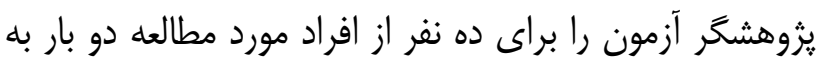

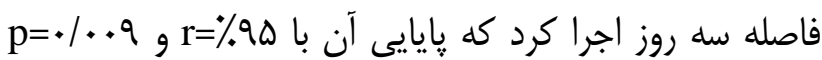
مورد تأييد قرار زرفت. براى گردآورى دادهها، در عآ ساعت سترفت اول بعد از زايمان،

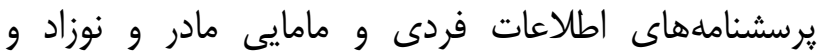

\footnotetext{
${ }^{2}$ Physical Activity Readiness Questionnaire (PAR-Q)
}

يس از برآورد حجم نمونه، يزوهشگر با در دست داشتن مجوزهاى مربوطه كه از طرف معاونت بثوهشى دانشخاه علوم يزشكى مشهد براى همكارى بيمارستانها با طرح تحقيقاتى مئى مراني حاضر صادر شده بود، به بيمارستانهاى امام رضا، قائم و

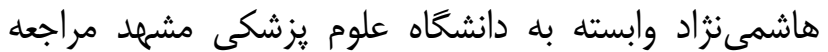
نمود و اقدام بله نمونه گيرى كرد. معيارهاى ورود به به مطالعه

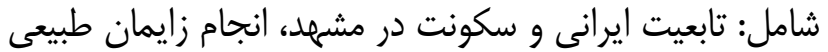

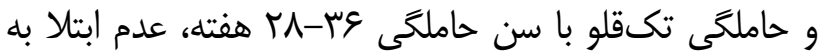

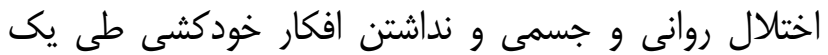

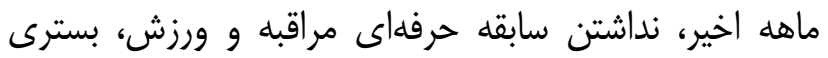

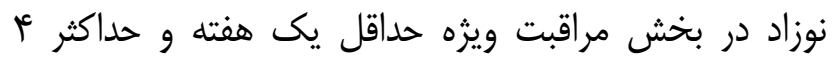

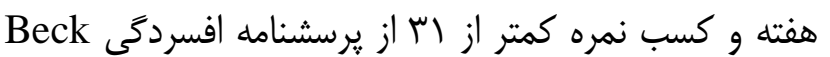
و معيارهاى خروج از مطالعه شامل: عدم تمايل به همكارى، فوت نوزاد حين مطالعه و ايجاد مشكلات ارتويدى حين انجام تمرينها بود. بيماران واجد شرايط مطالعه، يس از تكميل فرم رضايت

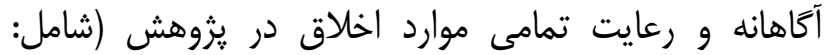
توضيح اهداف يزوهش به مادر با زبان ساده، هماهنگى با

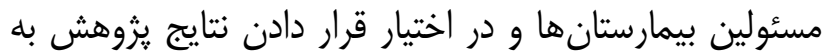
هر يك از افراد مورد مطالعه كه خواهان دريافت نتايج بودند) وارد مطالعه شدند (شكل يك). ابزار گردآورى دادهها شامل: فرم مشخصات فردى و مامايى افراد مورد مطالعه و يرسشنامه ئه

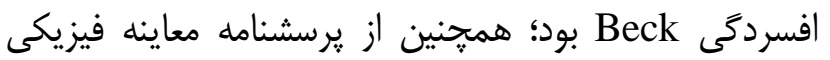

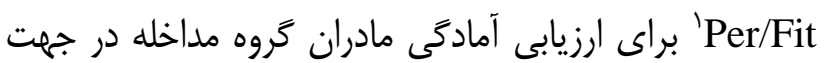
شروع تمرينها استفاده شد. فرم مشخصات فردى و مامايى افراد مورد مطالعه شامل

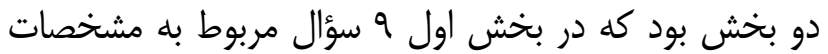

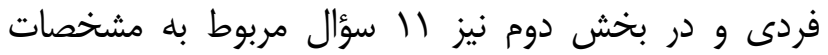

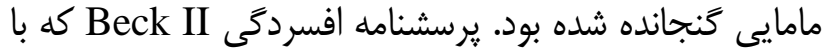

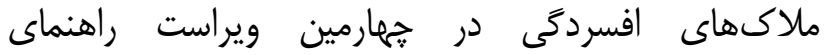
تشخيصى و آمارى اختلالهاى روانى (DSM-IV) منطبق

\footnotetext{
${ }^{1}$ Person-fit
} 
مطالعه (روز اس بعد زايمان) در گروه مداخله و در آخرين

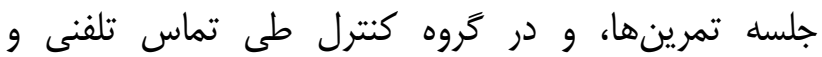
درخواست يثوهشگر از مادران براى حضور در بيمارستان محل

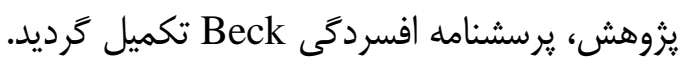
دادهها يس از گردآورى با استفاده از نرمافزار

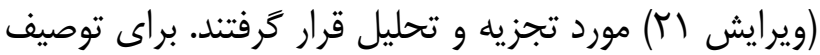

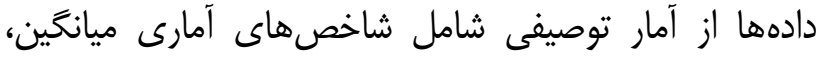

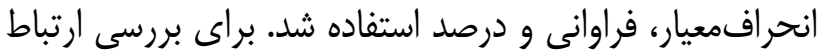

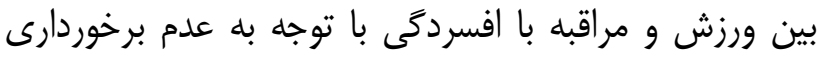

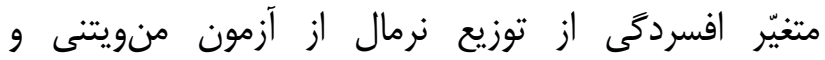

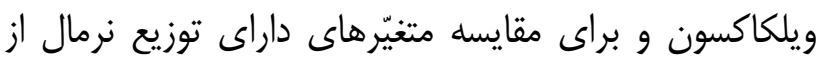

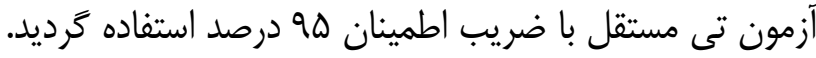

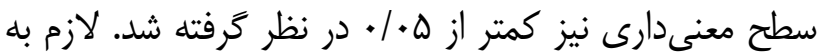

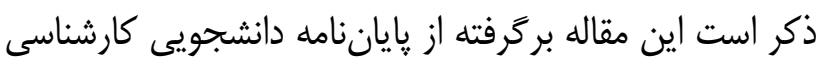

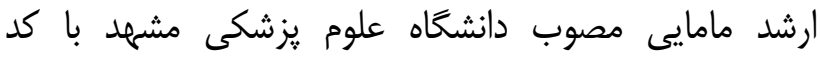

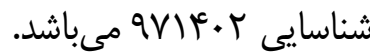

يافته ها

ميانگين سن زنان با زايمان زودرس مورد مطالعه در گروه مداخله

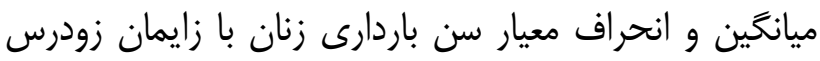

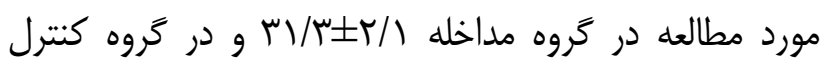
مداخله • مداخله و كنترل، داراى شغل خانهدارى بودند و از نظر سطح

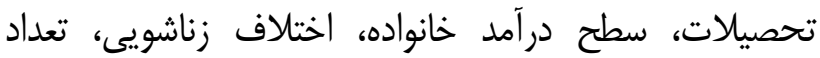
باردارى، تعداد زايمان، تعداد فرزند زنده، سابقه سقط، خواسيط

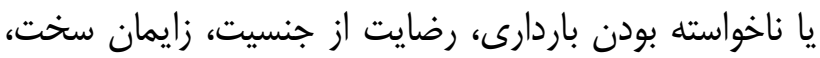

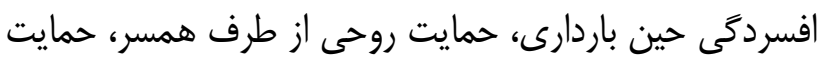

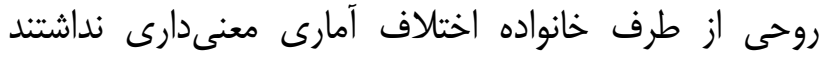

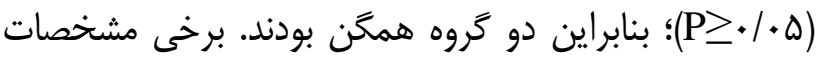
افراد مورد مطالعه در جدول يك به تفكيك آورده شده است.
افسردگى Beck در هر دو گروه تكميل شد و درگروه مداخله

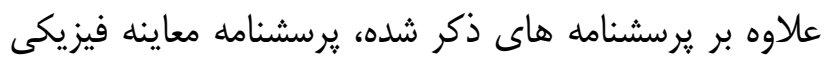

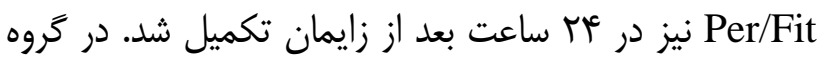

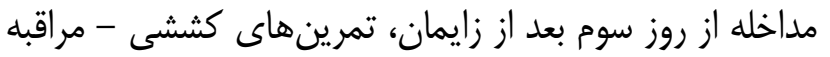

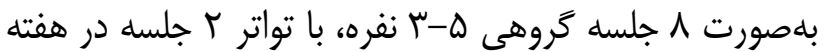

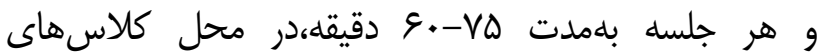

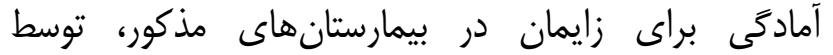

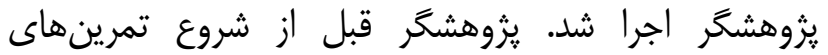

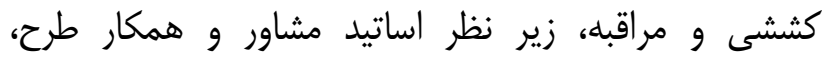

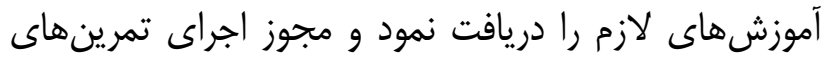

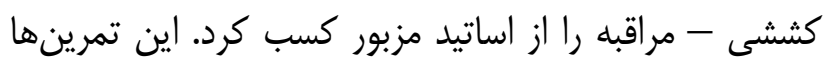

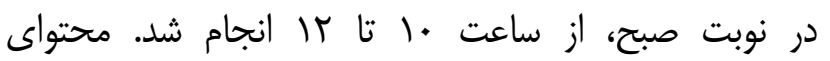

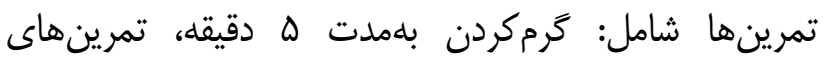

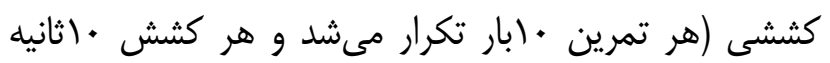

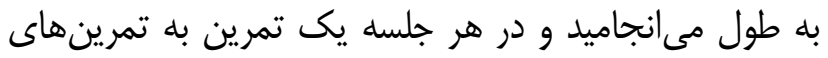

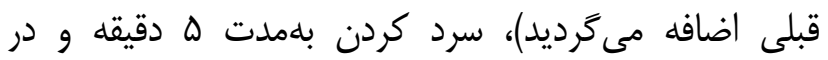

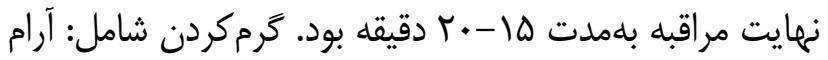

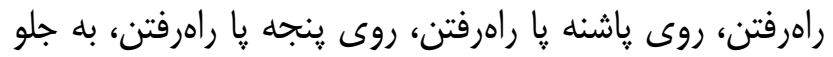

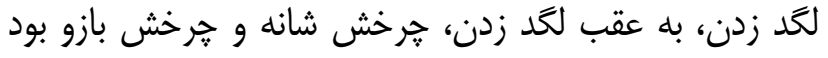

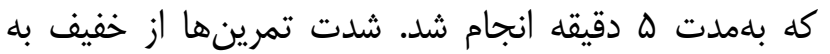

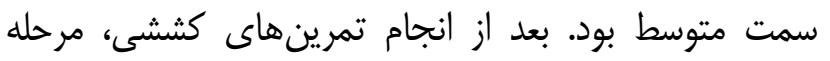

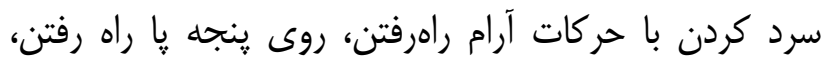

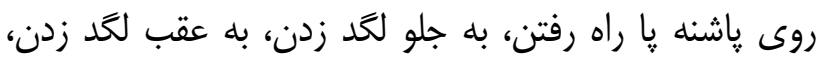

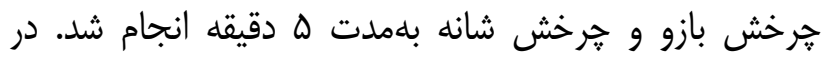

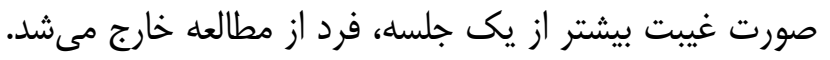

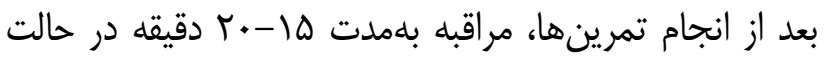

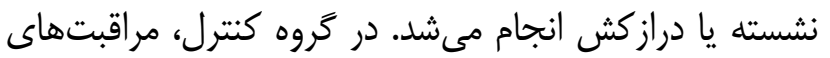

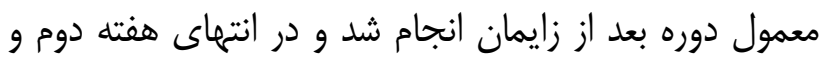
هفته جهارم بعد از شروع مطالعه، بهصورت تلفنى شرايط

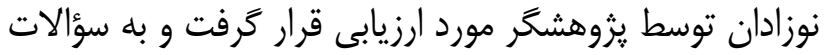

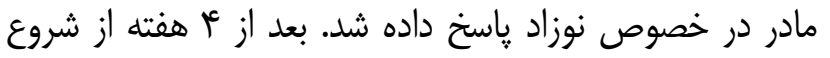




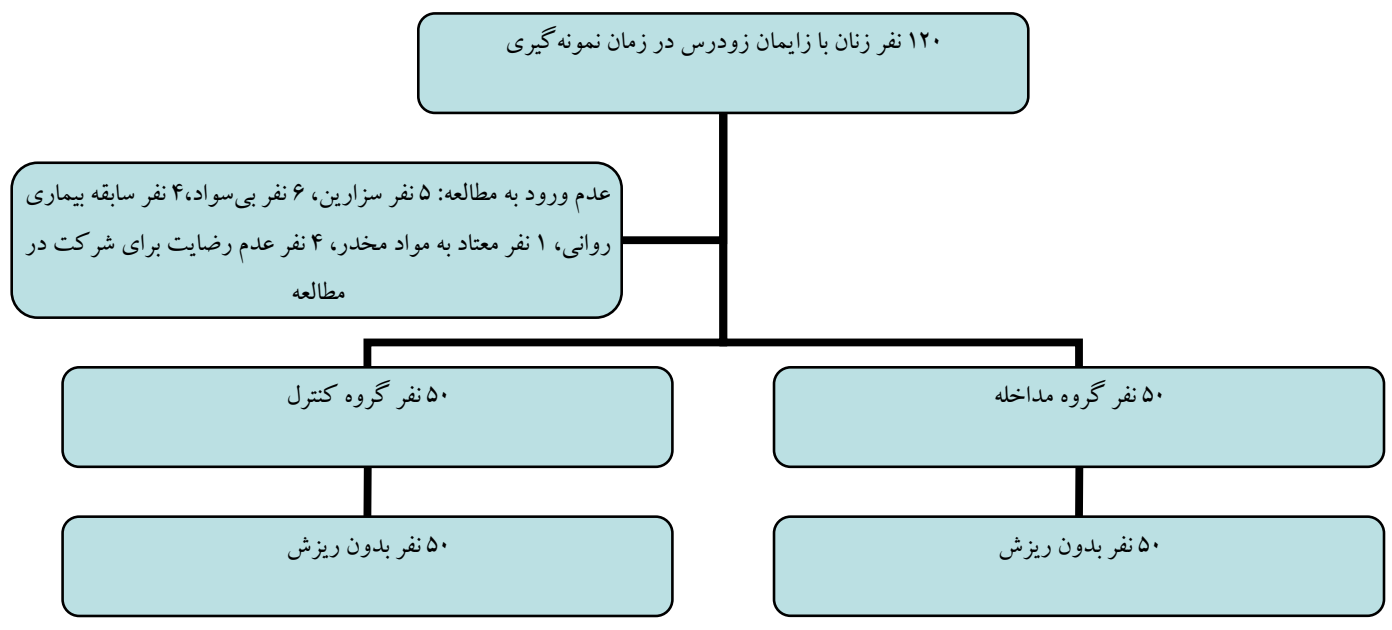

شكل ا - فلوجارت نحوه نمونه

جدول ا - مقايسه ميانكين اطلاعات دموكرافيك و مامايى زنان در دو گروه مورد مطالعه

\begin{tabular}{|c|c|c|c|}
\hline \multirow{3}{*}{ سطح معنىدارى } & \multicolumn{2}{|c|}{ كروه } & \multirow{3}{*}{ متغير } \\
\hline & $\begin{array}{c}\text { كنترل } \\
\text { (• ه نفر) }\end{array}$ & (• مداخله & \\
\hline & انحراف معيار土ميانگين & انحراف معيار_ميانگين & \\
\hline $\begin{array}{l}P=+/ \Lambda \& V \\
\text { تىمستقل }\end{array}$ & $r \Lambda / \digamma \pm \varphi / D$ & $r N / G \pm \xi / V$ & سن مادر (سال) \\
\hline $\begin{array}{l}\mathrm{P}=+/ \text { منويتنى } \\
\end{array}$ & $\mathrm{r} / / \Lambda \pm r /$. & $r / r \pm r / l$ & سن باردارى (هفته) \\
\hline 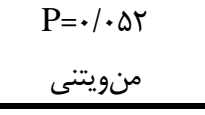 & $\varepsilon / \Lambda \pm r / r$ & $V / \cdot \pm \Lambda / \Delta$ & مدت زمان ليبر (ساعت) \\
\hline $\begin{array}{l}\mathrm{P}=/ \mathrm{A} \\
\text { منويتنى }\end{array}$ & $r / \Delta \Lambda \pm \cdot / \mathrm{\Lambda}$ & $r / \Lambda \pm \cdot / 9 T$ & مدت بسترى نوزاد در بخش مراقبت \\
\hline
\end{tabular}

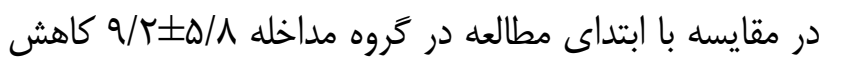

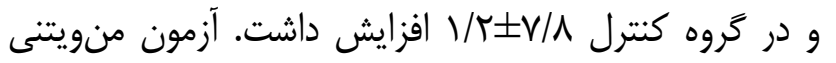

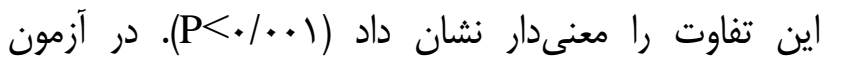

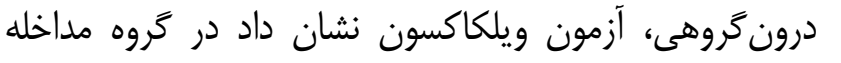

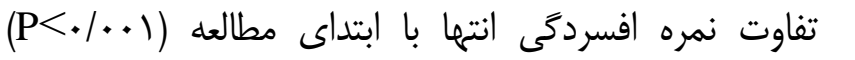

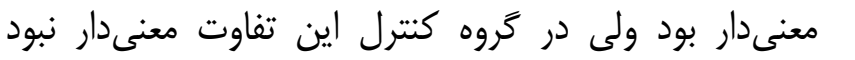
( جد (P=./VTS)
در ابتداى مطالعه، ميانكَين و انحراف معيار نمره افسردگى

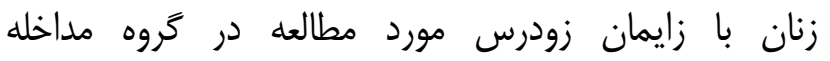

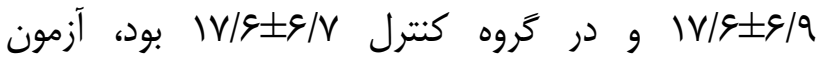

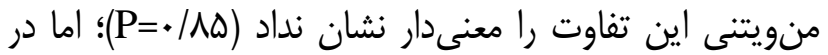

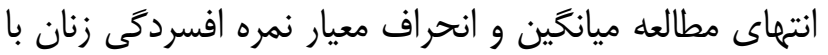

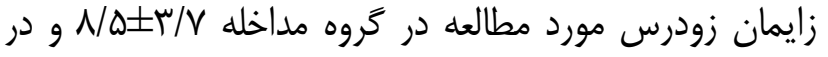

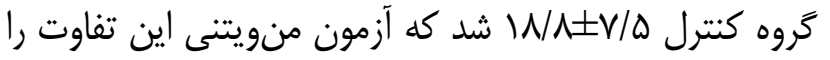

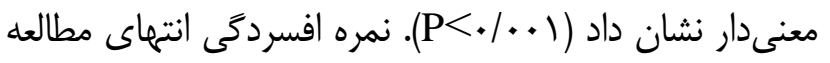


جدول r- مقايسه ميانكَين نمره افسردَى زنان با زايمان زودرس مورد مطالعه ابتدا و انتهاى مطالعه در دو تَروه مداخله و كنترل

\begin{tabular}{|c|c|c|c|}
\hline \multirow{3}{*}{ سطح معنىدارى آزمون } & \multicolumn{2}{|c|}{ 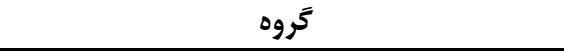 } & \multirow{3}{*}{ نمره افسردتى } \\
\hline & 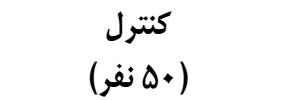 & مداخله & \\
\hline & انحراف معيار土ميانگين & معيار دميانكين & \\
\hline $\mathrm{P}=\cdot / \wedge \Delta$ & $\mathrm{IV} / \mathrm{g} \pm 9 / \mathrm{V}$ & $\mid V / q \pm \varepsilon / q$ & ابتداى مطالعه \\
\hline $\mathrm{P}<\bullet / .+1$ & $N / \Lambda \pm V / \Delta$ & $N / \Delta \pm \Gamma / V$ & انتهاى مطالعه \\
\hline $\mathrm{P}<\bullet / .+1$ & $1 / T \pm V / \Lambda$ & $-Q / \Upsilon \pm ه / \wedge$ & تفاوت انتهاى مطالعه در مقايسه با ابتداى مطالعه \\
\hline -_-_- & $\begin{array}{l}\mathrm{P}=\cdot / \mathrm{N} \\
\text { ويلكاكسون }\end{array}$ & $\begin{array}{l}\mathrm{P}<+.+1 \\
\text { ويلكاكسون }\end{array}$ & نتيجه آزمون درون كروهى \\
\hline
\end{tabular}

افسردگى مبتلا بودند و از اين نظر مىتوان گفت ورزش براى جامعه يزوهش وى نقش درمانى داشته است، اما در مطالعه ميله

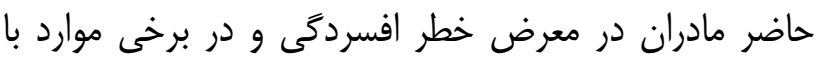
افسردگى در سطح خفيف وارد مطالعه شدند و مداخله توانست

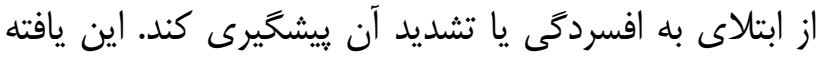

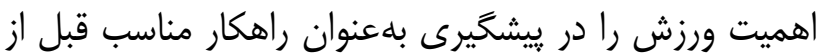

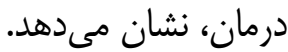
Chan

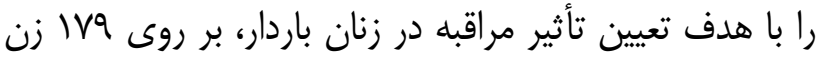

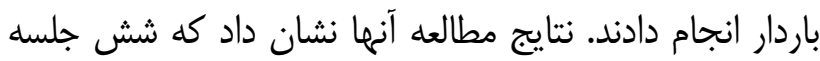

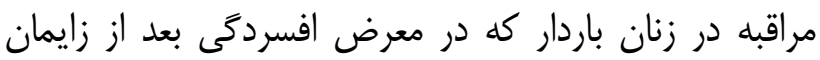
بودند اثرات مثبتى بر سلامت روان مادران در بعد از زايمان زايمان

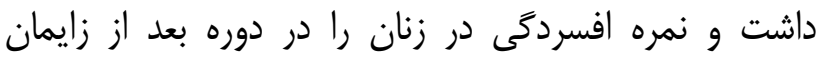

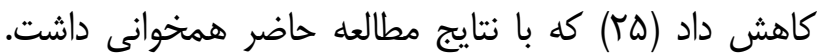

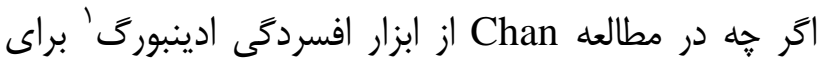

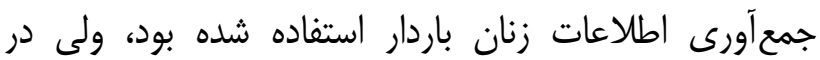

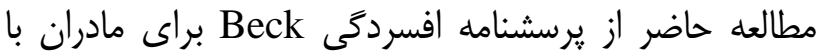
زايمان زودرس استفاده شد؛ با اين وجود در هر دو يزوهش إهـ نتايج يكسان بهدنبال مداخله از نوع مراقبه حاصل شد. ورزش

\section{${ }^{1}$ Edinburgh}

در مطالعه حاضر كه با هدف بررسى التأثير تمرينهاى

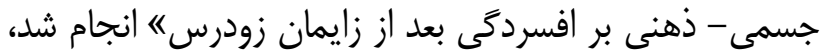

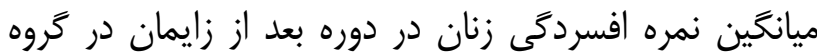
مداخله بلطور معنىدارى كاهش يافت. با وجود اينكه در

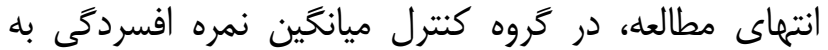
ميزان IJ/A/ I با افزايش همراه بود، اين افزايش از نظر

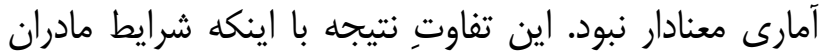

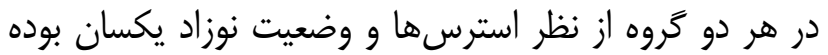

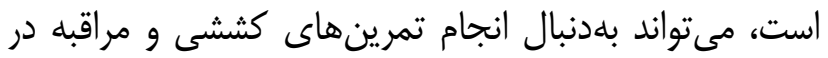
گروه مداخله اتفاق افتاده باشد.

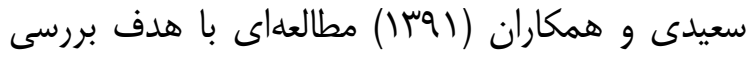

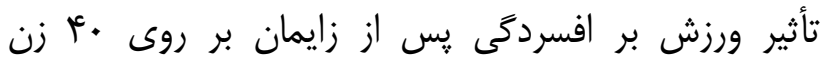
افسرده نخستزا در هفته צ-1 يس إز زايمان انجام دادند.

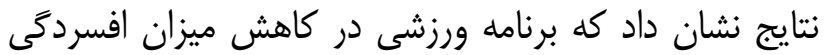

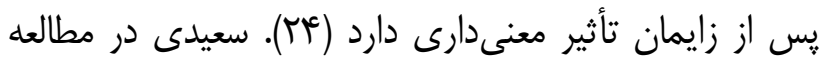
خود مداخله را أ هفته بعد از زايمان شروع كرده بود، در حالى كه در مطالعه حاضر سه روز بعد از زايمان مداخله انجام شد؛ با اين وجود نتايج مشابه، همخوانى دو مطالعه را نشان داد. البته

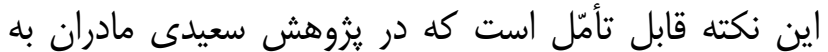


צ جلسه تمرين بهمدت سه هفته پِ از زايمان انجام شد.

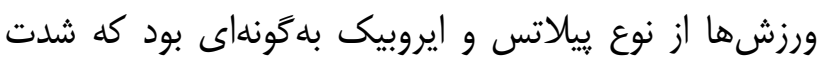

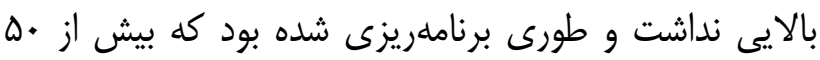

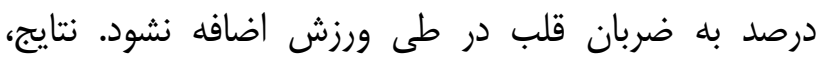

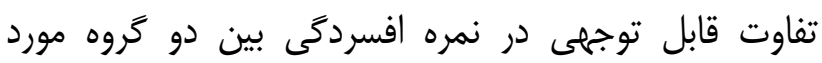

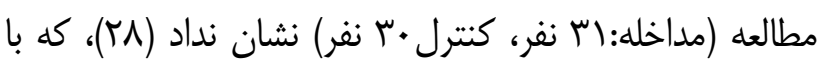

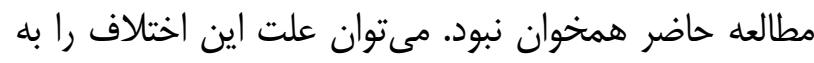

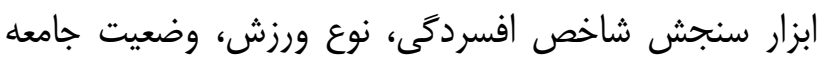

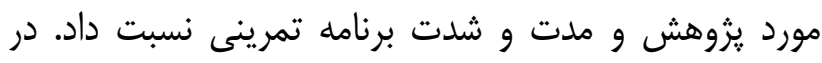

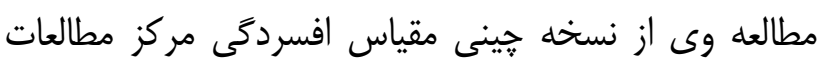

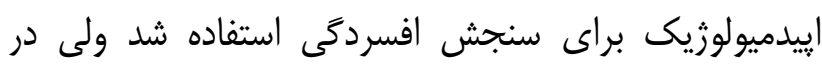

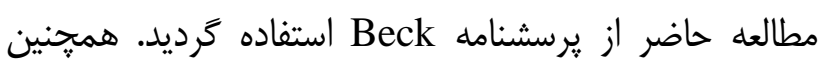

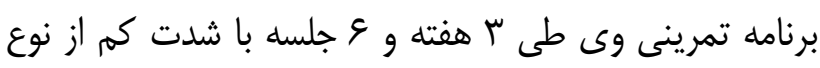

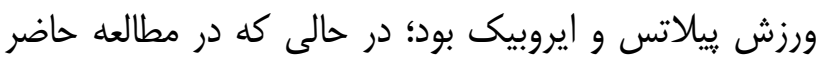

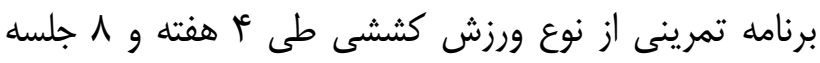

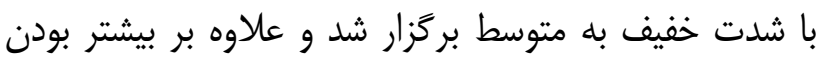

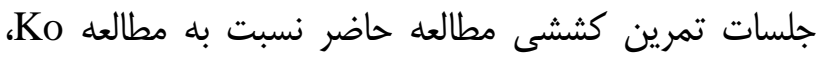

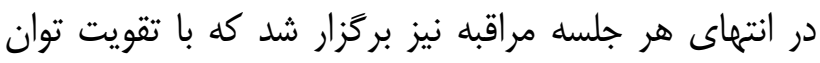

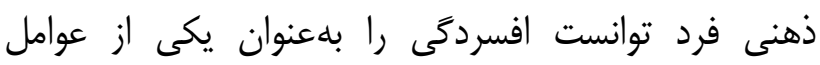

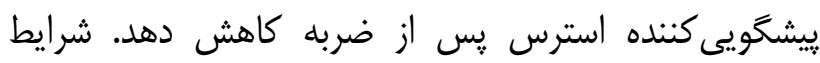
مادران شركت كننده در مطالعه حاضر از نظر عوامل استرسز إنسا

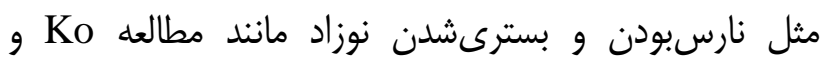

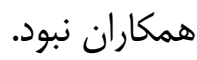
بلهعقيده محققين، ورزش در افراد افسرده حس اعتماد به

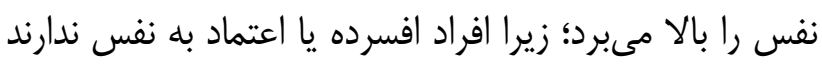

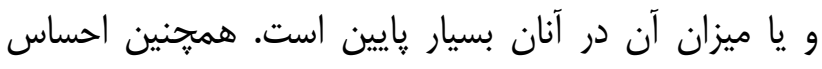

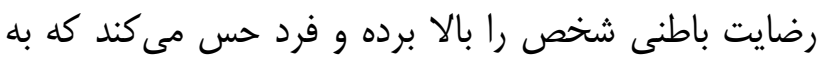

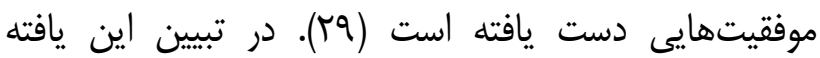

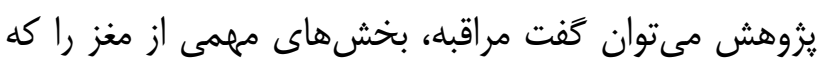

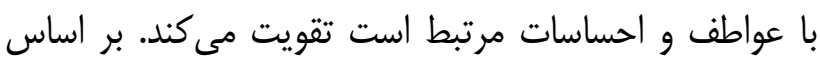
اين نظر، به غير از موسيقى، يوكا، ورزش و مطالعال، مراقبه نيز

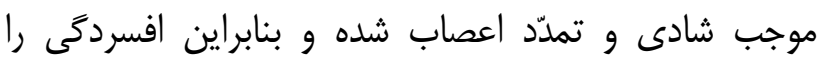

صحيح و مناسب سبب ترشح هورمونهاى سروتونين و

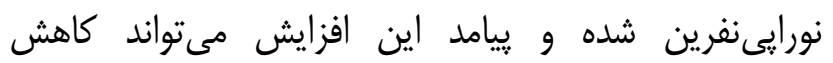

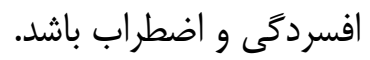
Zewditu كردند كه فعاليت فيزيكى در كاهش افسردكى بعد از زايمان

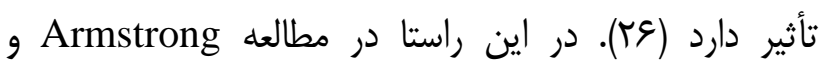

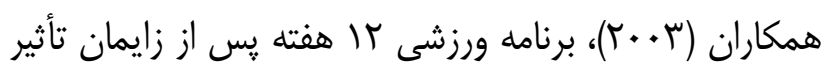

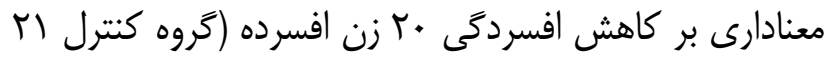

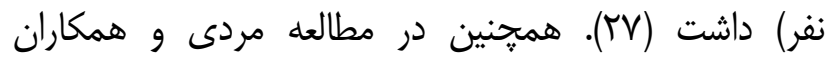

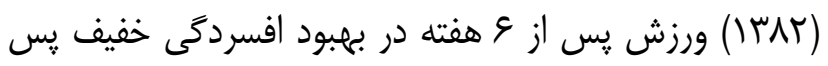

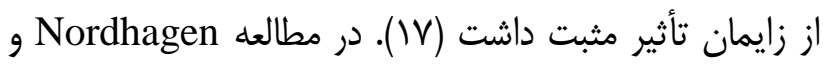

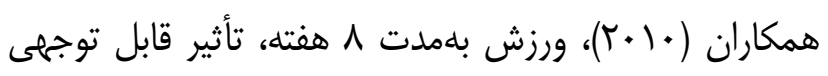

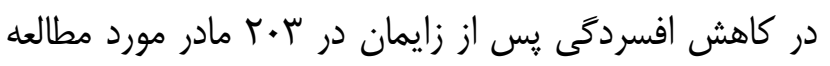

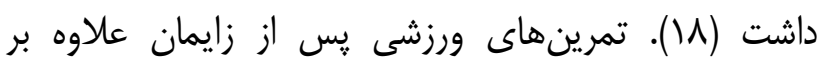

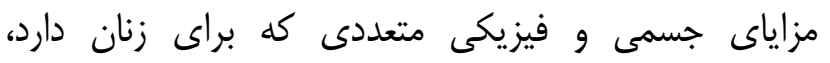

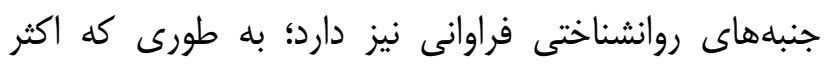

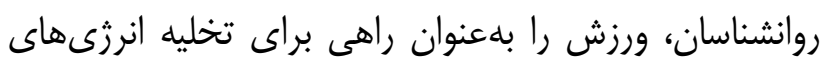
فيزيكى همراه با نشاط و شادابى ذهن بيان مى كنيند.

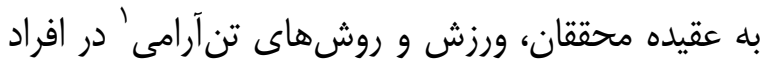
افسرده، حس اعتماد به نفس و احساس رضايت باطنى را بالا

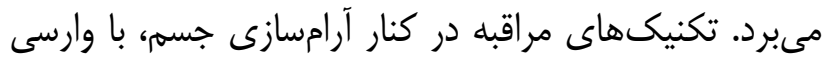

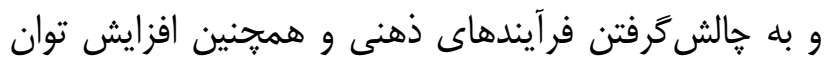

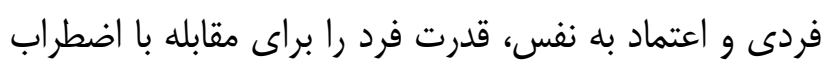

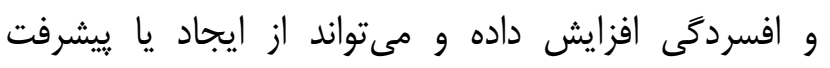

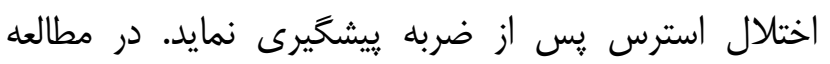

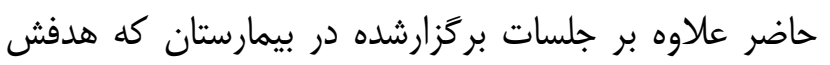

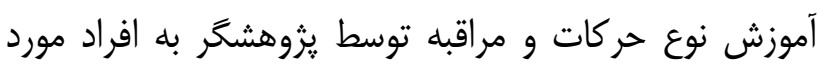

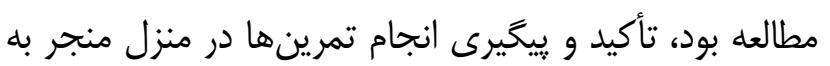

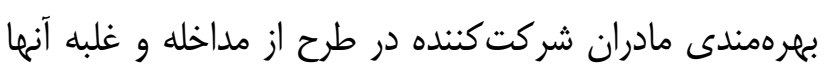

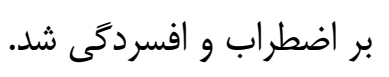

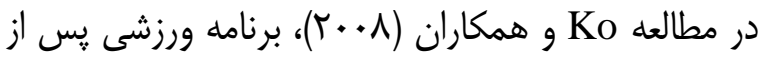




$$
\begin{aligned}
& \text { كاهش مىدهد (•rا). علاوه بر اين در مطالعه حاضر براى بلهعنوان روشى مناسب و بدون عارضه در زنان بعد از زايمان }
\end{aligned}
$$

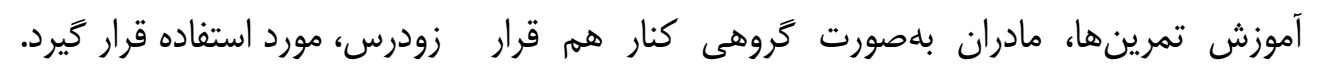

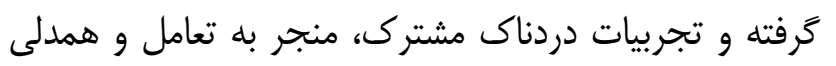

$$
\begin{aligned}
& \text { تقدير و تشكر }
\end{aligned}
$$

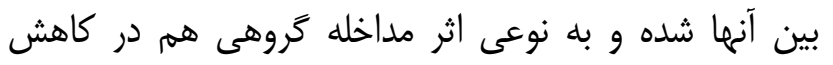

$$
\begin{aligned}
& \text { بدينوسيله از معاونت محترم يثوهشى دانشخاه علوم }
\end{aligned}
$$

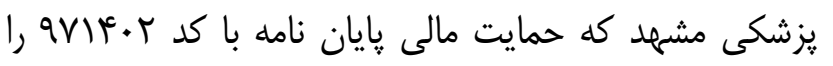

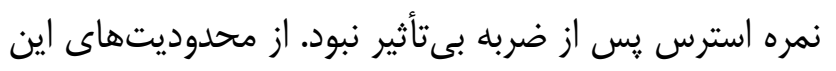

$$
\begin{aligned}
& \text { مطالعه مىتوان به عدم كورسازى اشاره كرد. }
\end{aligned}
$$

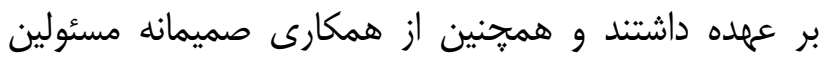

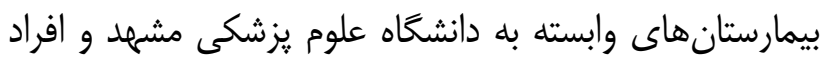

$$
\begin{aligned}
& \text { طبق نتايج حاصل از اين مطالعه، مىتوان بيان كرد كه شركت كننده در مطالعه، تشكر و قدردانى مىشود. }
\end{aligned}
$$

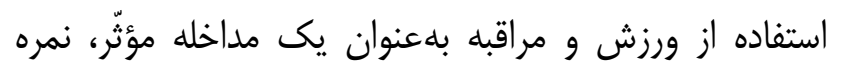

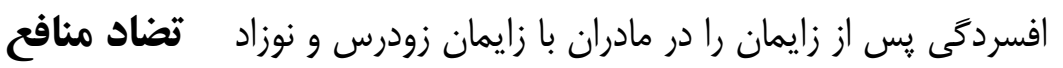

$$
\begin{aligned}
& \text { نويسندكان اعلام مىدارند هيج گَونه تضاد منافعى در ماضع } \\
& \text { يزوهش حاضر وجود ندارد. }
\end{aligned}
$$

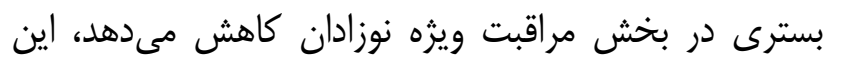

$$
\begin{aligned}
& \text { روش قابليت انجام در محيط بيمارستان را داشته و مورد مورد }
\end{aligned}
$$

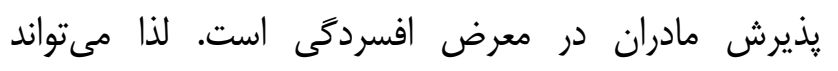

1- Deng AW, Xiong RB, Jiang TT, Luo YP, Chen WZ. Prevalence and risk factors of postpartum depression in a population-based sample of women in Tangxia Community, Guangzhou. Asian Pac J Trop Med. 2014; 7(3): 244-9. doi: 10.1016/S1995-7645(14)60030-4.

2- Seng JS, Rauch SA, Resnick H, Reed CD, King A, Low LK, et al. Exploring posttraumatic stress disorder symptom profile among pregnant women. J Psychosom Obstet Gynaecol. 2010; 31(3): 176-87. DOI: $10.3109 / 0167482 X .2010 .486453$

3- Breslau N, Roth T, Rosenthal L, Andreski P. Sleep disturbance and psychiatric disorders: a longitudinal epidemiological study of young adults. Biol Psychiatry. 1996; 39(6): 411-8. doi: 10.1016/0006-3223(95)00188-3

4- Sirati Nir M, Ebadi A, Fallahi Khoshknab M, Tavallaie A. Consequences of living with Posttraumatic Stress Disorder: A Qualitative Study. J Qual Res Health Sci. 2012; 1(2): 92-101. [Persian]

5- Shaw RJ, Brecht CJ, St. John N, Lilo E, Corcoran J, Jo B, et al. Prevention Of Postpartum Traumatic Stress In Mothers With Preterm Infants: Manual Development and Evaluation. Issues Ment Health Nurs. 2013; 34(8): 578-86. doi: 10.3109/01612840.2013.789943

6- Forcada-Guex M, Borghini A, Pierrehumbert B, Ansermet F, Muller-Nix C. Prematurity, maternal posttraumatic stress and consequences on the mother-infant relationship. Early Hum Dev. 2011; 87(1): 21-6. doi: 10.1016/j.earlhumdev.2010.09.006.

7- Shaw RJ, Lilo E, Benitz W, Storfer-Isser A, Ball MB, Proud M, et al. Screening for symptoms of postpartum traumatic stress in a sample of mothers with preterm infants. Issues Ment Health Nurs. 2014; 35(3): 198-207. doi: $10.3109 / 01612840.2013 .853332$.

8- Horsch A, Tolsa JF, Gilbert L, du Chêne LJ, Müller-Nix C, Bickle Graz M. Improving Maternal Mental Health Following Preterm Birth Using an Expressive Writing Intervention: A Randomized Controlled Trial. Child Psychiatry Hum Dev. 2016; 47(5): 780-91. doi: 10.1007/s10578-015-0611-6.

9- Shoja M, Shoja M, Shoja E, Gharaei M. Prevalence and affecting factors on preterm birth in pregnant women Referred to Bentolhoda hospital- Bojnurd. J North Khorasan Univ Med Sci. 2016; 7(4): 855-63. [Persian] DOI: 10.29252/jnkums.7.4.855 
10- Saeedi S. Effect of Exercise Program on Symptoms of Postpartum Depression. Iran J Obstet Gynecol Infertil. 2012; 15(34): 26-31. [Persian]

11- Rosenbaum S, Nguyen D, Lenehan T, Tiedemann A, van der Ploeg HP, Sherrington C. Exercise augmentation compared to usual care for post traumatic stress disorder: a randomised controlled trial (the REAP study: Randomised Exercise Augmentation for PTSD). BMC Psychiatry. 2011; 11: 115. DOI: 10.1186/1471-244X-11-115

12- Evenson KR, Mottola MF, Owe KM, Rousham EK, Brown WJ. Summary of International Guidelines for Physical Activity Following Pregnancy. Obstet Gynecol Surv. 2014; 69(7): 407-14. doi: 10.1097/OGX.0000000000000077.

13- Abedian Z, Safaei M, Mazlum SR, Hosseini SRA. The Effects of Performance Exercise on Stress in Midwives: A Clinical trial. Iran J Obstet Gynecol Infertil. 2014; 17(96): 12-20. [Persian]

14- Karimi A, Bahreinian SA, Ghobari Bonab B. An Investigation of the Impact of Meditation on Anxiety and Depression of Female Students. Clinical Psychology Studies. 2013; 3(9): 99-114. [Persian]

15- Jayatunge RM, Pokorski M. Post-traumatic Stress Disorder: A Review of Therapeutic Role of Meditation Interventions. In: Pokorski M. (eds) Respiratory Ailments in Context. Advances in Experimental Medicine and Biology. vol 1113. Springer, Cham; 2018. doi: 10.1007/5584_2018_167

16- Rosenthal JZ, Grosswald S, Ross R, Rosenthal N. Effects of Transcendental Meditation in Veterans of Operation Enduring Freedom and Operation Iraqi Freedom With Posttraumatic Stress Disorder: A Pilot Study. Mil Med. 2011; 176(6): 626-30. DOI: 10.7205/MILMED-D-10-00254

17- Mardi A, Molavi P, Tazakori Z, Mashoufi M, Aminisani N. The Effect of Physical Exercise on Mild Postpartum Depression among Women Referring to Ardabil Health Centers, 2002. J Ardabil Univ Med Sci. 2003; 3(4): 44-8. [Persian]

18- Nordhagen IH, Sundgot-Borgen J. [Physical activity among pregnant women in relation to pregnancy-related complaints and symptoms of depression]. Tidsskr Nor Laegeforen. 2002; 122(5): 470-4. [Norwegian]

19- Chan KP. Effects of perinatal meditation on pregnant Chinese women in Hong Kong: a randomized controlled trial. J Nurs Educ Pract. 2015; 5(1): 1-18. DOI: 10.5430/jnep.v5n1p1

20- Association AP. Diagnostic and statical manual of mental disorders:DSM-5. tehran: roshd; 2016.

21- Goodarzi MA. The study of reliability and validity of beck hopelessness scale in a group of shiraz university students. Journal of Social Sciences and Humanities of Shiraz University. 2002; 18(2): 27-39. [Persian]

22- Warburton DE, Jamnik V, Bredin SS, Shephard RJ, Gledhill N. The 2015 Physical Activity Readiness Questionnaire for Everyone (PAR-Q+) and electronic Physical Activity Readiness Medical Examination (ePARmedX+). The Health \& Fitness Journal of Canada. 2015;8(1):53-6.

23- Stefan-Dabson K, Mohammadkhani P. Psychometrics Characteristic of Beck Depression Inventory-II in Patients with Magor Depressive Disorder. Archives of Rehabilitation. 2007; 8(29): 80-6. [Persian]

24- Saeedi S. Effect of exercise program on symptoms of postpartum depression. Iran J Obstet Gynecol Infertil. 2013; 15(34): 26-31. [Persian]

25- Chan KP. Prenatal meditation influences infant behaviors. Infant Behav Dev. 2014; 37(4): 556-61. doi: 10.1016/j.infbeh.2014.06.011.

26- Demissie Z, Siega-Riz AM, Evenson KR, Herring AH, Dole N, Gaynes BN. Associations between physical activity and postpartum depressive symptoms. J Womens Health (Larchmt). 2011; 20(7): 1025-34. doi: 10.1089/jwh.2010.2091.

27- Armstrong K, Edwards H. The effects of exercise and social support on mothers reporting depressive symptoms: a pilot randomized controlled trial. Int J Ment Health Nurs. 2003; 12(2): 130-8. DOI: 10.1046/j.1440-0979.2003.00229.x

28- Ko YL, Yang CL, Chiang LC. Effects of postpartum exercise program on fatigue and depression during "doing-themonth" period. J Nurs Res. 2008; 16(3): 177-86. DOI: 10.1097/01.jnr.0000387304.88998.0b

29- Stathopoulou G, Powers MB, Berry AC, Smits JA, Otto MW. Exercise interventions for mental health: a quantitative and qualitative review. Clinical Psychology: Science and Practice. 2006; 13(2): 179-93. DOI: $10.1111 / \mathrm{j} .1468-2850.2006 .00021 . \mathrm{x}$

30- Won JS, Kim JH. [Study on ego states in the view of transactional analysis, coping style and health states of nursing students]. J East-West Nurs Res. 2002; 7(1): 68-81. [Korean] 